The People Want 
The publisher gratefully acknowledges the generous support of the Joan Palevsky Literature in Translation Endowment Fund of the University of California Press Foundation. 


\section{The People Want}

A Radical Exploration of the Arab Uprising

\section{Gilbert Achcar}

Translated from the French by G.M. Goshgarian

따

UNIVERSITY OF CALIFORNIA PRESS

Berkeley • Los Angeles • London 
University of California Press, one of the most distinguished university presses in the United States, enriches lives around the world by advancing scholarship in the humanities, social sciences, and natural sciences. Its activities are supported by the UC Press Foundation and by philanthropic contributions from individuals and institutions. For more information, visit www.ucpress.edu.

University of California Press

Berkeley and Los Angeles, California

University of California Press, Ltd.

London, England

(C) 2013 by The Regents of the University of California

Library of Congress Cataloging-in-Publication Data

Achcar, Gilbert.

The people want : a radical exploration of the Arab uprising / Gilbert Achcar.

pages $\mathrm{cm}$

ISBN 978-0-520-27497-6 (hardback)

ISBN 978-0-520-2805 I-9 (pbk)

I. Arab Spring, 20IO- 2. Protest movements-Arab countries-History-2ist century. 3. RevolutionsArab countries-History-2 Ist century. 4. Arab countries-Politics and government-2 Ist century. 5. Arab countries-Economic conditions-2Ist century. 6. Youth-Political activity-Arab countries. 7. Unemployment-Arab countries. 8. Information technology-Political aspects-Arab countries. I. Title. JQI850.A9IA336 20I3 909'.0974927083I2-dc23

Manufactured in the United States of America

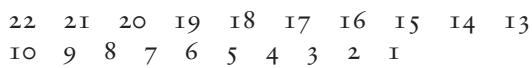

In keeping with a commitment to support environmentally responsible and sustainable printing practices, UC Press has printed this book on Rolland EnviroI00, a I00\% post-consumer fiber paper that is FSC certified, deinked, processed chlorine-free, and manufactured with renewable biogas energy. It is acidfree and EcoLogo certified. 